\title{
ANALISIS KONTRIBUSI DAN DAYA SAING EKSPOR SEKTOR PERIKANAN PROVINSI NUSA TENGGARA BARAT
}

\author{
Wildan Al Farizi ${ }^{a^{*}}$, Mariyana Sari ${ }^{\mathrm{a}}$, Mochammad Fattah ${ }^{\mathrm{a}}$ \\ ${ }^{a}$ Sosial Ekonomi Perikanan dan Kelautan, \\ Fakultas Perikanan dan Ilmu Kelautan, Universitas Brawijaya \\ *Koresponden penulis : wildanalfarizi@ub.ac.id
}

\begin{abstract}
Abstrak
Tujuan dari penelitian ini adalah menganalisis kontribusi dan daya saing sektor perikanan Provinsi Nusa Tenggara Barat. Jenis penelitian yang digunakan adalah library research dengan teknik pengumpulan data melalui dokumentasi. Analisis data kuantitatif yang digunakan adalah kontribusi dan daya saing (RCA). Perikanan darat memberikan kontribusi $53,7 \%$ terhadap sektor perikanan lebih tinggi daripada perikanan laut sebesar 46,3\%. Kontribusi nilai ekspor sektor perikanan terhadap nilai ekspor provinsi Nusa Tenggara Barat masih rendah sebesar $0,26 \%$. Nilai daya saing ekspor perikanan provinsi Nusa Tenggara Barat terhadap provinsi lain sebesar 0,09 atau lebih kecil dari 1 sehingga kemampuan daya saing lemah. Pemerintah NTB bersama masyarakat perikanan memanfaatkan potensi perikanan darat untuk meningkatkan kontribusi dan daya saing.
\end{abstract}

Kata kunci: perikanan darat, perikanan laut, kontribusi dan daya saing ekspor

\begin{abstract}
The purpose of this study is to analyze the contribution and competitiveness of the West Nusa Tenggara Province fisheries sector. The type of research is a library research with data collection techniques through documentation. Quantitative data analysis used is contribution and competitiveness (RCA). Inland fisheries contributed $53.7 \%$ give fisheries sector higher than marine fisheries by $46.3 \%$. The contribution of the export value of the fisheries sector to the export value of the province of West Nusa Tenggara is still low at $0.26 \%$. The value of fisheries export competitiveness in the province of West Nusa Tenggara against other provinces is 0.09 or smaller than 1 , so that the competitiveness ability is weak. The NTB government together with the fishing community exploits the potential of inland fisheries for increase their contribution and competitiveness.
\end{abstract}

Keywords: inland fisheries, sea fisheries, contribution and export competitiveness

\section{PENDAHULUAN}

Peranan sub-sektor perikanan dalam pembangunan nasional yang utama sebagai penghasil bahan pangan protein hewani, mendorong pertumbuhan agroindustri, sumber devisa, menciptakan lapangan kerja, peningkatan pendapatan dan kesejahteraan pembudidaya ikan dan nelayan serta menunjang pembangunan daerah [1]. Optimalisasi pengembangan potensi sumberdaya alam dan pemilihan sektor yang diprioritaskan sebagai upaya peningkatan peran dan kontribusi terhadap PDRB [2].

Provinsi Nusa Tenggara Barat mempunyai dua pulau besar adalah pulau
Lombok dan pulau Sumbawa dengan luas wilayah masing-masing mencapai $4.738,80$ $\mathrm{Km}^{2}(23,51 \%)$ dan $15.414,05 \mathrm{Km}^{2}(76,49 \%)$ dari luas wilayah daratan. Sementara Luas perairan laut mencapai 59,13 persen dari luas wilayah Nusa Tenggara Barat atau sekitar $29.159,04 \mathrm{Km}^{2}$ yang dikelillingi 278 pulaupulau kecil dengan panjang garis pantai sekitar $2.333 \mathrm{Km}$ [3].

Produksi perikanan darat dan laut di Provinsi Nusa Tenggara Barat dari 8 Kabupaten dan 2 Kota. Produksi perikanan darat mulai tahun 2008-2018 rata-rata sebesar 124.684,79 ton/ tahun dari 15 spesies, sedangkan produksi perikanan laut rata-rata sebesar 737.117,43 ton/ tahun dengan 71 jenis spesies.

Produk ekonomis penting perikanan 
Nusa Tenggara Barat adalah rumput laut, cumi-cumi, tongkol, cakalang, kakap merah, dan ikan karang $[4,5,6]$. Produksi perikanan laut berdasarkan BPS 2019 Provinsi Nusa Tenggara adalah kerapu, layang, teri, tembang, lemuru, kembung, cakalang, tongkol, rajungan, ubur-ubur, rumput laut, cumi-cumi. Komoditas perikanan laut yang menghasilkan produksi tertinggi di NTB adalah rumput laut dan tongkol. Sedangkan produksi perikanan darat berdasarkan BPS 2015 adalah ikan mas, tawes, mujair, nila, gurami, bawal air tawar, lele, bandeng, belut, udang windu, rumput laut, udang vanamei, dan patin. Komoditas perikanan darat yang menghasilkan produksi tertinggi di

NTB adalah udang vanamei.[7], menyebutkan bahwa ikan Tuna, Cakalang dan Tongkol (TCT) adalah jenis ikan ekonomis penting Indonesia.

Komoditas unggulan sektor perikanan laut merupakan salah satu komoditas strategis untuk meningkatkan pendapatan asli daerah [8]. Faktor yang mempengaruhi tingkat daya saing ekspor udang indonesia yaitu: jumlah tenaga kerja, lahan, program pemerintah, jumlah produksi, modal, diversifikasi, lingkungan, pakan, benih, permintaan, harga, pesaing, standard dan kualitas. Tingkat daya saing serta kinerja ekspor dapat diukur dengan metode RCA [9]. Tujuan dari penelitian ini adalah menganalisis kontribusi dan daya saing sektor perikanan Provinsi Nusa Tenggara Barat

\section{METODE ANALISIS DATA}

\section{Pengambilan Data}

Penelitian analisis kontribusi dan daya saing ekspor sektor perikanan Provinsi Nusa Tenggara Barat dilaksanakan pada bulan Januari 2020. Penelitian ini menggunakan jenis penelitian library research dengan teknik pengumpulan data berupa dokumentasi. Data dokumentasi yang digunakan adalah BPS dalam angka Provinsi Nusa Tenggara Barat mulai tahun 2015-2019.

Analisis data kuantitaif yang digunakan adalah kontribusi dan daya saing sektor perikanan Provinsi Nusa Tenggara. Rumus yang digunakan untuk menghitung kontribusi, yaitu:

I. Kontribusi Perikanan

$$
\text { Kontribusi Perikanan }=\frac{\text { Nilai Perikanan }_{i}}{\text { Nilai Sektor Perikanan Total }}
$$

II. Kontribusi Ekspor Perikanan

$$
\text { Kontribusi Ekspor Perikanan }=\frac{\text { Nilai Ekspor Perikanan NTB }}{\text { Nilai Ekspor Perikanan Indonesia }}
$$

III. Rumus untuk menghitung daya saing, yaitu:

$$
R C A=\frac{x i}{x t} / \frac{X i}{X t}
$$

Keterangan:

$\mathrm{xi}=$ Nilai Ekspor Perikanan Nusa Tenggara Barat

$\mathrm{xt}=$ Nilai Ekspor Non-Migas Nusa Tenggara Barat

$\mathrm{Xi}=$ Nilai Ekspor Perikanan Indonesia

$\mathrm{Xt}=$ Nilai Ekspor Non-Migas Indonesia

Hasil RCA yang didapatkan lebih besar dari satu maka Negara tersebut memiliki keunggulan komparatif dalam komoditinya dan memiliki daya saing kuat. Sebaliknya negara memiliki nilai RCA kurang dari satu maka negara tersebut tidak memiliki keunggulan komparatif dalam komoditinya dan memiliki daya saing lemah [10].

Peramalan daya saing provinsi NTB menggunakan trend kuadratik dengan software MINITAB. Persamaan kuadratik [11] sebagai berikut: $\mathrm{Y}=\mathrm{a}+\mathrm{bX}+\mathrm{cX} 2$

\section{HASIL DAN PEMBAHASAN}

\section{Kontribusi Perikanan Provinsi Nusa Tenggara Barat}

Produksi perikanan Nusa Tenggara Barat perikanan darat dan perikanan laut berdasarkan volume mulai tahun 2008-2018 mengalami kenaikan (Gambar 1a). Kenaikan produksi perikanan laut lebih tinggi daripada perikanan darat, akan tetapi pada (Gambar 1b) perikanan darat menghasilkan nilai lebih tinggi daripada perikanan laut. Hal ini disebabkan perikanan darat mengoptimalkan produksi ikan ekonomis yaitu: udang. Ratarata per tahun nilai yang dihasilkan dari produksi perikanan darat sebesar Rp.4.902,09 Milyar, sedangkan perikanan laut sebesar Rp.3348,18 Milyar. Nilai produksi perikanan darat diatas rata-rata mulai tahun 2013-2018, 
sedangkan nilai produksi perikanan laut mulai tahun 2014-2018.

Faktor-faktor yang mempengaruhi produksi tambak adalah luas tambak, nener, pupuk, tanggungan keluarga dan kondisi wilayah berpengaruh signifikan terhadap produksi ikan bandeng, sedangkan variabel tenaga kerja, pakan, umur dan pengalaman usaha tambak tidak berpengaruh [12]. Variabel Modal berpengaruh positif dan signifikan terhadap jumlah produksi usaha tambak ikan, sedangkan variabel Luas Lahan dan Tenaga Kerja tidak berpengaruh signikan dan positif [13].

Luas kolam dan dana penguatan modal secara bersama berpengaruh terhadap produktivitas dan pendapatan usaha pembesaran ikan dan secara parsial luas kolam berpengaruh secara signifikan terhadap produktivitas tetapi dana penguatan modal tidak berpengaruh, luas kolam secara parsial berpengaruh pula terhadap pendapatan tetapi dana penguatan modal secara parsial tidak berpengaruh terhadap pendapatan. Produktivitas berpengaruh terhadap pendapatan usaha pembesaran ikan air tawar [14].

Kenaikan pakan lebih mempunyai resiko daripada biaya operasional lain terhadap usaha budidaya. Usaha pembesaran ikan gurame lebih sensitif atau mempunyai resiko tinggi ketika penerimaan mengalami penurunan daripada biaya yang mengalami kenaikan [15].

Hasil produksi dengan alat tangkap purse sein dipengaruhi oleh faktor-faktor secara nyata yaitu ukuran kapal, daya mesin kapal, panjang

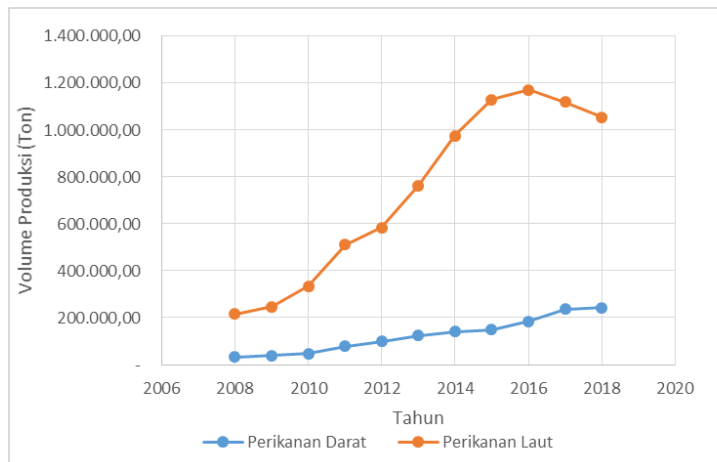

a. Volume Perikanan

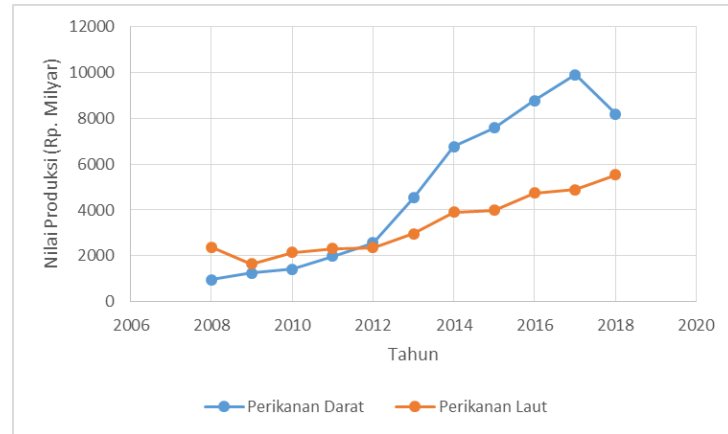

b. Nilai Perikanan

Gambar 1. Volume dan Nilai Produksi Perikanan Darat dan Laut

Pemanfaatan sumberdaya perikanan harus mempertimbangkan ekologi sehingga ekonomi berkelanjutan [16]. Peningkatan produksi perikanan darat dan laut provinsi Nusa Tenggara Barat mengalami pertambahan yang semakin menurun (Gambar 2). Rata-rata pertambahan volume produksi perikanan darat mulai tahun 2008-2018 sebesar 23\%, sedangkan perikanan laut sebesar $18 \%$. Hal ini disebabkan produksi perikanan laut dipengaruhi oleh musim ikan karena pada tahun 2017 dan 2018 mengalami penurunan produksi.

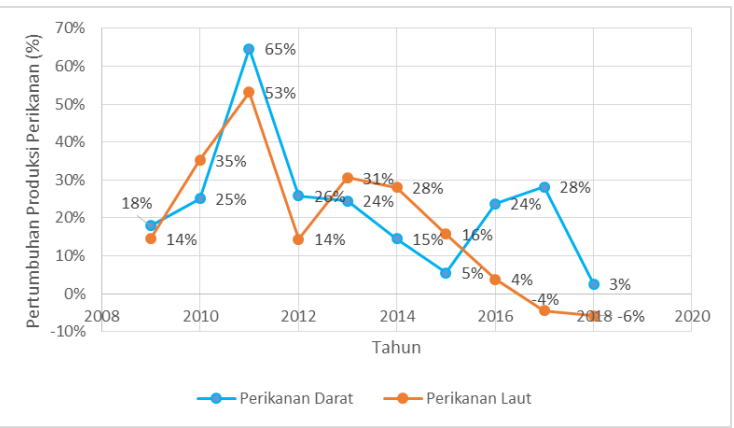

Gambar 2. Persentase Pertumbuhan Produksi Perikanan

Sumberdaya alam yang dapat menjadi penggerak ekonomi wilayah mempunyai kriteria sebagai berikut: (1) memiliki kontribusi penting dalam tingkat regional; (2) adanya keterkaitan dengan sektor lain, dan; (3) mempunyai dampak pengganda [17]. Kontribusi perikanan darat terhadap sektor perikanan pada tahun 2008-2011 dibawah perikanan laut. Kontribusi perikanan darat mulai tahun 2012-2018 lebih tinggi daripada perikanan laut (Gambar 3). Volume produksi ikan laut lebih tinggi daripada perikanan darat, akan tetapi nilai produksi 
perikanan darat lebih tinggi daripada perikanan laut sehingga kontribusi perikanan darat lebih tinggi terhadap sektor perikanan.

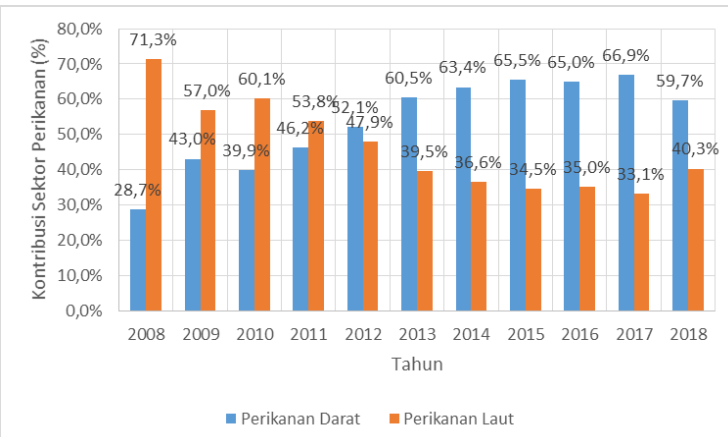

Gambar 3. Perbandingan Kontribusi Perikanan Darat dan Laut Terhadap Sektor Perikanan

Volume ekspor perikanan dan udang Indonesia dan provinsi Nusa Tenggara Barat mulai tahun 2015-2018 mengalami peningkatan. Volume ekspor perikanan Indonesia tertinggi pada tahun 2018 sebesar 1.126.079 ton, sedangkan terendah pada tahun 2016 sebesar 1.075.000 ton. Volume ekspor tertinggi pada tahun 2017 sebesar 1.139,09 ton sedangkan terendah pada tahun 2016 sebesar 604,52 ton. Secara umum nilai perikanan Indonesia (Gambar 3a) dan NTB (Gambar 3b) mengalami peningkatan.

Nilai rata-rata kontribusi ekspor perikanan terhadap ekspor non-migas NTB sebesar $0,26 \%$, sedangkan kontribusi perikanan Indonesia sebesar 3,02\%. Maka kontribusi ekspor perikanan NTB belum memberikan kontribusi yang besar terhadap ekspor, akan tetapi kontribusi nilai ekspor perikanan NTB mengalami peningkatan (Gambar 4c). Terdapat pengaruh positif yang signifikan dari Produksi Udang Domestik dan pengaruh negatif yang signifikan dari Harga Udang Internasional terhadap Volume Ekspor Udang dari Indonesia ke Jepang, sedangkan Nilai Tukar Rupiah terhadap US\$ memiliki pengaruh yang tidak signifikan terhadap Volume Ekspor Udang dari Indonesia ke Jepang [18].

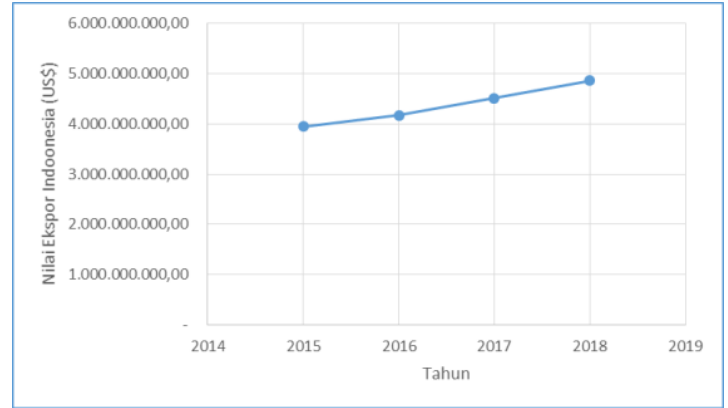

a) Nilai Ekspor Perikanan Indonesia

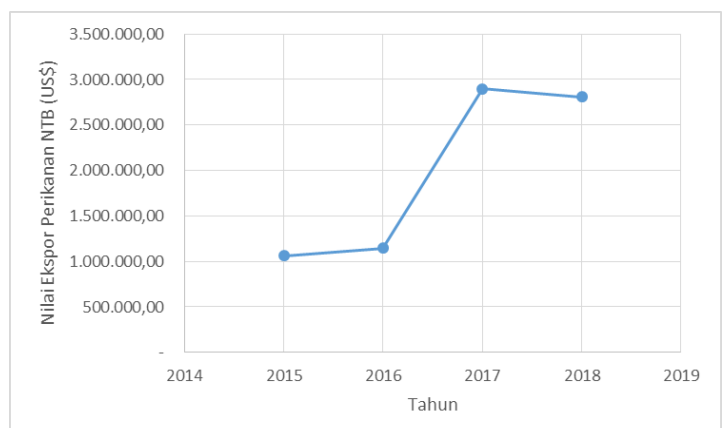

b) Nilai Ekspor Perikanan NTB

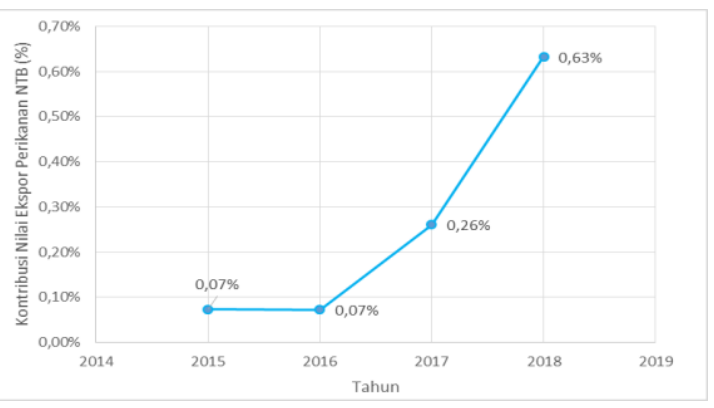

c) Persentase Kontribusi Nilai Ekspor Perikanan NTB

Gambar 4. Persentase Kontribusi Nilai Ekspor Perikanan NTB

\section{Daya Saing Ekspor Provinsi Nusa Tenggara Barat Terhadap Provinsi Lain di Indonesia}

Pembangunan perikanan Indonesia merupakan suatu kegiatan ekonomi yang memiliki prospek semakin baik, terutama dalam meningkatkan penerimaan devisa negara melalui ekspor hasil perikanan [19]. Nilai ekspor non-migas Indonesia mulai tahun 2015-2018 mengalami peningkatan, sedangkan provinsi Nusa Tenggara Barat mengalami penurunan (Gambar 5). Nilai ekspor non-migas Indonesia tertinggi pada tahun 2018 sebesar US\$ 162.841.000.000, sedangkan terendah pada tahun 2015 sebesar US\$ 131.791.900.000 (Gambar 5a). Nilai ekspor non-migas NTB tertinggi pada tahun 
2016 sebesar US\$ 1.585.666.400, sedangkan terendah pada tahun 2018 sebesar US\$ 443.688.910 (Gambar 5b).

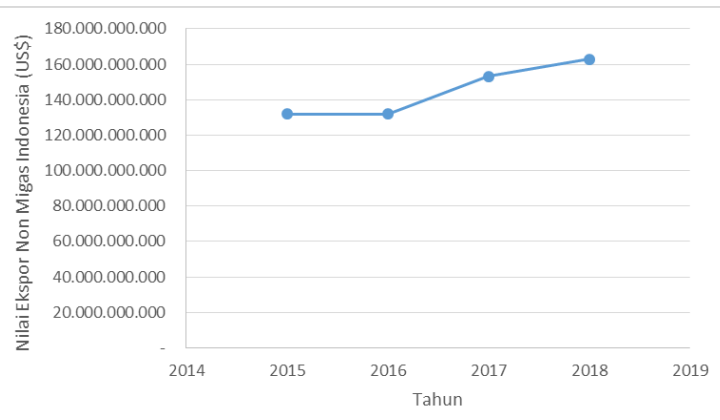

a. Nilai Ekspor Non Migas Indonesia

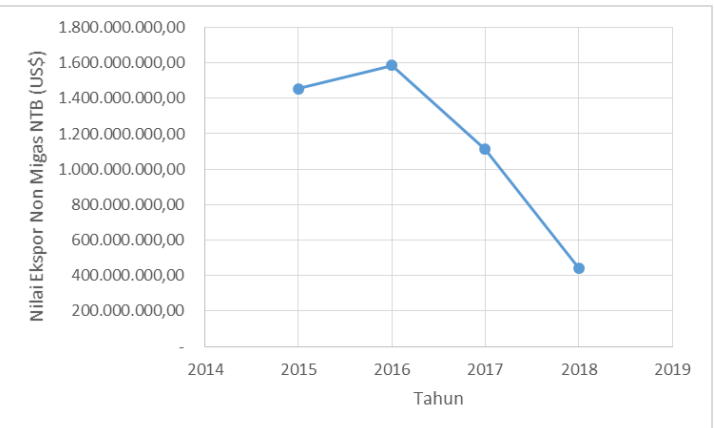

b) Nilai Ekspor Non Migas NTB

Gambar 5. Nilai Ekspor Non-Migas

Nilai daya saing nilai ekspor perikanan Provinsi Nusa Tenggara Barat terhadap provinsi lain di Indonesia rata-rata sebesar 0,09 artinya bahwa ekspor perikanan NTB mempunyai daya saing yang masih lemah karena dibawah 1 (Gambar 6). Indonesia terdapat 6 provinsi yang memberikan kontribusi ekspor hasil perikanan tertinggi adalah Jawa Timur, DKI Jakarta, Maluku, Sulawesi Selatan, Sumatra Utara, dan Papua Barat karena provinsi tersebut memiliki pelabuhan besar yang aktif melakukan kegiatan ekspor ke luar negeri maupun antar provinsi [20].

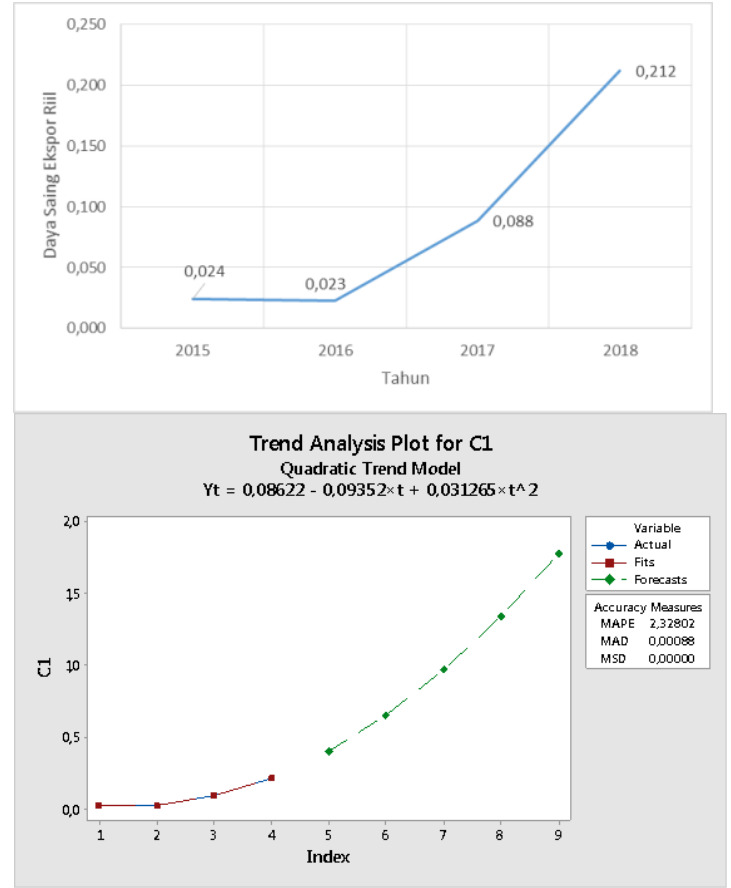

Gambar 6. Nilai Daya Saing Ekspor Perikanan Riil (atas) dan Ekspor Estimasi (bawah) NTB Terhadap Provinsi Lain

Provinsi Nusa Tenggara Barat berdasarkan estimasi dengan persamaan trend kuadratik $\mathrm{Y}=0,08622-0,09352 \mathrm{X}+0,031265 \mathrm{X}^{2}$ akan mempunyai daya saing ekspor perikanan yang lebih kuat atau lebih besar 1 mulai tahun 2022 dengan nilai sebesar 1,34. Pada tahun 2023 daya saing ekspor perikanan meningkat menjadi 1,78 .

\section{KESIMPULAN DAN SARAN}

Provinsi Nusa Tenggara Barat mempunyai produksi perikanan darat dan laut yang meningkat setiap tahun, perikanan darat lebih memberikan kontribusi daripada perikanan laut. Sektor perikanan memberikan kontribusi nilai ekspor yang relatif lebih rendah dan daya saing Provinsi NTB masih lemah.

Saran yang dapat diberikan dari penelitian ini adalah pemerintah dan masyarakat perikanan bekerjasama dalam meningkatkan produksi perikanan darat dan mengoptimalkan produksi perikanan laut dengan menggunakan teknologi tepat guna dan ramah lingkungan. 


\section{DAFTAR PUSTAKA}

[1] Tibrani. (2018). Peranan Sub Sektor Perikanan dalam Menunjang Perekonomian Kabupaten Kampar Provinsi Riau. Jurnal Agribisnis Volume 20 Nomor 02, Desember 2018: 206-2017.

[2] Kaihatu M.M. (2018). Kontribusi Sektor Perikanan dalam Perekonomian Kabupaten Maluku Tengah. Jurnal Matematika, Saint, dan Teknologi, Volume 19, Nomor 1, Maret 2018: 5771.

[3] KKP. (2018). Potensi Usaha dan Peluang Investasi Kelautan dan Perikanan Provinsi Nusa Tenggara Barat. KKP. Jakarta

[4] Hidayat A. dan Purnami S. (2019). Pengembangan Komoditas Rumput Laut Nusa Tenggara Barat Dengan Model Hexagon Untuk Pembangunan Ekonomi Lokal. J. Kebijakan Sosek KP Voume 9 Nomor 01, Juni 2019: 45-55.

[5] Santoso D., Mulyono S. B., Domu S., Yopi N. dan Mustaruddin. (2015). Status Pemanfaatan Ikan di Selat Alas Propinsi Nusa Tenggara Barat. J. Lit. Perikan. Ind. Volume 21 Nomor 02 Juni 2015: 8794.

[6] Yulianto E.Y.F., Wazir M., dan F. Purwangka. (2019). Penentuan Lokasi Penangkapan Ikan Karang Di Kawasan Konservasi Perairan Gita Nada, Lombok Barat. Jurnal IPTEKS PSP. Volume 5 Nomor 10, Oktober 2018.

[7] Kushendarto, S., Fattah, M., Sari, M., \& AlFarizi, W. (2018). Analysis of Contribution Tuna Cakalang Tongkol (TCT) on Regional Bruto Domestic Revenues in Tulungagung Regency. ECSOFiM (Economic and Social of Fisheries and Marine), 5(2), 167-172.

[8] Ridwan M., Mauli K. dan Andi R.S.P. (2018). Penentuan Komoditas Unggulan Perikanan Laut Kabupaten Polewali Mandar Berdasarkan Data Statistik Tahun 2016. Jurnal IPTEKS PSP.
Volume 5 Nomor 10, Oktober 2018: 98105.

[9] Mufa'ah dan Mardiyah H. (2016). Analisis Daya Saing Ekspor Komoditas Udang Indonesia. Jurnal AGRIFO Volume 01 Nomor 01, April 2016: 1-20.

[10] Wahyudi A.F., Joni H. dan Anisya R. (2019). Analisis Daya Saing Udang Indonesia di Pasar Indonesia. Forum Agribisnis Volume 9, No. 1 Maret 2019: 1-16.

[11] Fattah, M., Tiwi, N. U., \& Candra, A. I. (2017). Analisis Potensi dan Peluang Pengembangan Sub Sektor Perikanan Tangkap Laut Di Kabupaten Malang. ECSOFiM: Journal of Economic and Social of Fisheries and Marine, Volume 4 Nomor 02, 135-143.

[12] Marhawati dan M. Imam M. (2018). Analisis Faktor-Faktor yang Mempengaruhi Produksi Ikan Bandeng di Kecamatan Ma'rang Kabupaten Pangkep. Jurnal Ekonomi dan Pendidikan Volume 01 Nomor 02, Juli 2018: 50-57

[13]Munandar A. dan C. Putri M.S. (2019). Faktor-Faktor Yang Mempengaruhi Jumlah Produksi Usaha Tambak Ikan Di Gampong Batuphat Barat Kecamatan Muara Satu Kota Lhokseumawe. Jurnal Ekonomi Regional Unimal Volume 02 Nomor 01 April 2019: 51-62.

[14] Andayani S.A. (2016). Faktor-Faktor yang Mempengaruhi Produktivitas dan Pendapatan Usaha Pembesaran Ikan Air Tawar. Jurnal Ilmu Pertanian dan Peternakan Volume 4 Nomor 2 Desember 2016: 206-213.

[15] Fattah, M., Utami, T. N., \& Sofiati, D. (2019). Financial Feasibility and Sensitivity of The Enlargement Gouramy (Osphronemus Gouramy) Business at Susuhbango Village, Kediri Regency. ECSOFiM (Economic and Social of Fisheries and Marine), Volume 6 Nomor 02, 202-208 
[16] Edi, S., Pudji, P., \& Mochammad, F. (2018). Analysis on Economical and Ecological Potential Benefits Of Artificial Coral Reefs Planting Activities. RJOAS, Volume 12 Nomor 72, December 2017: 268-273.

[17] Adinugroho G. (2016). Potensi SubSektor Perikanan Untuk Pengembangan Ekonomi di Bagian Selatan Gunungkidul. J. Sosek KP Volume 11 Nomor 2 Desember 2016:173-183.

[18] Kusumawati L.A., M.A. Musadieq dan Sri S. (2016). Pengaruh produksi, Harga dan Nilai Tukar Terhadap Volume Ekspor (Studi Pada Volume Ekspor Udang Dari Indonesia Ke Jepang Periode Tahun 2012-2014). Jurnal Administrasi Bisnis (JAB) | Volume 39 Nomor 01, Oktober 2016: 65-72.

[19] Putri D.A.S., Firman R., dan Made S.S. (2018). Daya Saing Ekspor dan Perkembangan Pangsa Pasar Ikan Tuna Indonesia di Pasar Internasional Periode 2012-2016. Ekonomi dan Bisnis Volume 23 Nomor 01, November 2018:1-18

[20] BPS. (2012). Statistik Ekspor Hasil Perikanan Menurut Komoditi, Provinsi dan Pelabuhan Asal Ekspor. Pusat Data, Statistik, dan Informasi. Jakarta. 
